\title{
The 'New Urban Science': towards the interdisciplinary and transdisciplinary pursuit of sustainable transformations
}

Andrew Karvonen* ${ }^{*}$, Vladimir Cvetkovic, Pawel Herman, Karl Johansson, Hedvig Kjellström, Marco Molinari and Mikael Skoglund

${ }^{*}$ Correspondence: apkar@kth.se

KTH Royal Institute of Technology, 100 44 Stockholm, Sweden

\begin{abstract}
Digitalisation is an increasingly important driver of urban development. The 'New Urban Science' is one particular approach to urban digitalisation that promises new ways of knowing and managing cities more effectively. Proponents of the New Urban Science emphasise urban data analytics and modelling as a means to develop novel insights on how cities function. However, there are multiple opportunities to broaden and deepen these practices through collaborations between the natural and social sciences as well as with public authorities, private companies, and civil society. In this article, we summarise the history and critiques of urban science and then call for a New Urban Science that embraces interdisciplinary and transdisciplinary approaches to scientific knowledge production and application. We argue that such an expanded version of the New Urban Science can be used to develop urban transformative capacity and achieve ecologically resilient, economically prosperous, and socially robust cities of the twenty-first century.
\end{abstract}

\section{Highlights}

- The New Urban Science leverages digital tools and techniques to develop new knowledge that can inform urban development processes.

- Interdisciplinary and transdisciplinary approaches are critical to expanding and enhancing digital modes of urban scientific knowledge production.

- An expansive approach to the New Urban Science can be used to develop urban transformative capacity by fostering communities of learning to leverage the commonalities and differences between and within cities.

Keywords: New Urban Science, Interdisciplinary, Transdisciplinary, Urban transformative capacity 


\section{Policy and practice recommendations}

- Urban scientists need to embrace pluralist approaches to knowledge production that draw upon the natural and social sciences.

- Urban science practices can be enhanced through engagement with a wide range of urban stakeholders beyond the academy.

- The ultimate aim of the New Urban Science should be to develop actionable knowledge to diagnose and address urban problems.

\section{Introduction}

In the last two decades, the 'New Urban Science' has rapidly emerged as an enticing way to apply digital tools and techniques to some of the most challenging issues faced by cities (Lobo et al. 2020). The New Urban Science involves computer and information scientists taking advantage of the significant increases in computational power and data generation to study cities (Townsend 2015a). The New Urban Science is significant because it presents a new chapter in the co-evolution of technology, cities, and society. There is a strong emphasis on generating and analysing Big Data to understand urban processes while optimising urban functions through the application of machine learning, artificial intelligence, augmented reality, and human-computer interactions (Duarte and Ratti 2018; Ying et al. 2019). This increase in computational ability and data availability has revolutionised the ability to simulate and model complex systems (Shutters 2018). In effect, the New Urban Science serves as a new mandate for scientists to systematically interpret and apply digital techniques to develop new insights about how cities function.

At the same time, the rise of the New Urban Science raises important questions about how digitally-informed knowledge practices can and should be organised and implemented to inform sustainable urban transformations (Derudder and van Meeteren 2019; Duminy and Parnell 2020; Kitchin 2020). The aim of this article is to reflect on the potential of the New Urban Science to more effectively support the sustainable transformation of twenty-first century cities. We begin with a brief overview of the rise of the New Urban Science and how it leverages digitalisation to provide new insights on urban development processes. We then summarise the main critiques of this emerging scientific approach to cities and highlight alternative approaches that embrace interdisciplinary and transdisciplinary modes of knowledge production. We argue that such a pluralist and engaged approach can be used to build urban transformative capacity while ensuring that all urban stakeholders benefit from scientific knowledge production and application.

\section{The rise of the 'New Urban Science'}

Urban development has always been closely intertwined with scientific inquiry and technological development. From the earliest Chinese, Egyptian, and Greek settlements to the present day, scientific and technological experts have aspired to rationalise cities (Townsend 2015b). In the Global North, the modern era of city planning that emerged in the late nineteenth century was dominated by engineers and public health experts who 
applied the scientific method to the design, construction, and maintenance of city-wide infrastructure networks as well as their attendant administrative structures (Schultz and McShane 1978; Graham and Marvin 2001; Melosi 2008). The rise of the modern city in the twentieth century was accompanied by the rise of urban science, a systematic and rigorous approach uses scientific principles to analyse and model urban development patterns and processes (Solecki et al. 2013; Townsend 2015b; Alberti 2017; Shelton 2017).

In the post-World War II period, urban science was bolstered by fundamental advances in computing power that allowed scientists to model urban functions and predict patterns of growth and change (Light 2003; Townsend 2015c; Shelton 2017). The mainstreaming of the World Wide Web in the late 1990s introduced new networking capabilities for urban science and spurred a wave of new programmes, initiatives, research centres, and laboratories to develop and apply quantitative computational approaches to analyse urban dynamics (Townsend 2015b). The contemporary focus on smart cities has further invigorated urban science practices through the introduction of Big Data, ubiquitous sensor networks, datahubs, control centres, and other digitally networked artefacts and systems (Batty 2013; Marvin and Luque-Ayala 2017; Karvonen et al. 2019; Kitchin 2020). In short, digitalisation is fuelling a 'scientific urban renaissance' (Parnell and Robinson 2018: 17) with multiple opportunities to know cities more intimately and then use these insights to address existing social, economic, and environmental problems (Batty 2013; Ramaswami et al. 2018; Ying et al. 2019; Bettencourt 2021).

Today, the New Urban Science is being developed in world-leading academic research centres such as University College London's Centre for Advanced Spatial Analysis, the MIT Senseable City Lab, the Queensland University of Technology Urban Informatics Research Lab, New York University's Center for Urban Science and Progress, the University of Chicago's Centre for Urban Computation and Data, and Delft University of Technology and Wageningen University's Amsterdam Institute for Advanced Metropolitan Solutions (Townsend 2015b; Karvonen 2020; Lobo et al. 2020). Researchers at these centres use the latest computational approaches to enrich 'how we understand, explain, and predict city processes' (Duminy and Parnell 2020: 650). In effect, the computational and information sciences are introducing new ways of knowing and acting upon cities (Townsend 2015b).

\section{Alternative perspectives on urban science}

Urban science has evolved significantly over the last hundred years but the desire to rationalise and improve cities through the application of science and technology has not always been received favourably by urban practitioners and the general public. LeGates et al. (2009: 763) note that:

Since the beginning of the last century urban planners have alternately embraced rational planning, rigorous scientific methods, and exploitation of technology, only to reject scientific city planning when the application of the technology and the theory of the day failed to produce the overly optimistic results advocates had promised. 
The 1960s and 1970s were a significant period of contestation about rational, expertdriven approaches to urban development as social scientists, political activists, and neighbourhood groups called for the opening up of urban development processes to a wider range of voices and concerns (Fainstein 2014; Townsend 2015a; Jepson Jr 2019). Inspired by the seminal work of Jane Jacobs as well as numerous community advocates, they argued that the development of cities and the wellbeing of urban residents should not be restricted to a small number of scientific and technical experts. Instead, these issues should be informed by the democratic input of all urban stakeholders through participatory planning processes. As American Pragmatist John Dewey (1927[1954]: 207) famously remarked, 'The man who wears the shoe knows best that it pinches and where it pinches, even if the expert shoemaker is the best judge of how the trouble is to be remedied.' The aim is to ensure that those most affected by scientific and technological approaches to urban development have a say in how these practices were conducted. This is readily apparent in today's debates about smart cities. For example, the 2020 collapse of the Sidewalks Labs proposal to develop a new, cutting-edge smart district in Toronto illustrates the tensions between digitalisation and the politics of urban development (Carr and Hesse 2020; Morgan and Webb 2020).

To address these political aspects of urban development, it is necessary to go beyond the computational, quantitative approaches to the New Urban Science. The social sciences have a longstanding but often underacknowledge tradition of scientific knowledge production in cities through planning, geography, political science, sociology, anthropology, and other urban disciplines. A key inspiration for these urban science practices is the Chicago School of Sociology of the 1910s and 1920s where researchers used Chicago as an urban laboratory to collect empirical data on lived conditions (Park and Burgess 2019). Today, the Chicago School approach to urban science is reflected in citizen science, urban living laboratories, collaboratories, and other grounded, participatory activities that engage a wide range of stakeholders in the co-production of urban futures (Evans et al. 2016; Marvin et al. 2018; Ying et al. 2019; Calzada 2020; Karvonen et al. 2020). These research activities are largely absent in discussions about the New Urban Science due to disciplinary biases and less engagement with digitalisation processes. However, they make important contributions to how urban scientists know and act upon cities.

\section{Extending and enhancing the new urban science}

Combining the quantitative, universal approaches of the computer and information sciences with the situated, particular approaches of the social sciences has the potential to enhance and broaden the New Urban Science beyond the current narrow focus on urban data analytics and systems modelling. Such an expansive approach can continue to exploit the opportunities afforded by digitalisation tools and techniques while opening up these practices to a wider range of perspectives. Arguably, much if not all of the urban science conducted today could and should be part of the New Urban Science. However, as Acuto et al. (2018: 3) note:

Today's urban research, far from being a coherent 'urban science', remains trapped in the twentieth-century tradition of the systematic study of individual cities and the rise of specialized academic disciplines and professions associated with, amongst 
others, economics, health, planning, engineering, and design.

To be sure, mono-disciplinary approaches continue to be useful and necessary to study urban conditions but they are often insufficient to address the 'wicked problems' faced by today's cities (Rittel and Webber 1973; Solecki et al. 2013; Zellner and Campbell 2015). These problems include the climate crisis, global pandemics, rising social inequalities, economic precarities, and a host of other issues. Thus, the New Urban Science arguably requires a fundamental reframing of how scientific practices in cities are conducted, by whom, and for which purposes. There is a need to break out of the traditional disciplinary silos of scientific practice to realise the full potential of digitally-enhanced knowledge production. This is what makes the New Urban Science so exciting while simultaneously so daunting.

An important first step in broadening the scope of the New Urban Science is to recognise that urban knowledge is founded upon particular ontological and epistemological assumptions that are neither self-evident nor universally shared. Urban science is often assumed to be objective, singular, and neutral but critics are quick to point out that this embodies a particular framing of cities (Kitchin 2016, 2020; Shelton 2017; Parnell and Robinson 2018; Lobo et al. 2020). Historically, urban science has been dominated by the 'hard sciences,' and specifically physics and computer science, where the city is interpreted as a series of mechanistic systems involving linear metabolic processes that can be optimised and balanced (Berry 1964; Healey and Hillier 2010; Batty 2012; Söderström et al. 2014). This is appealing because it involves the production of knowledge that is 'generalizable, verifiable and transferable' (Parnell and Robinson 2018: 22). However, such a positivistic perspective on cities has been critiqued by the 'soft sciences' as reductionist, mechanistic, and deterministic (Kitchin et al. 2015; Kitchin 2016, 2020; Shelton 2017; Duminy and Parnell 2020).

In the last three decades, this divide between the natural and social sciences has been bridged with an updated systems perspective that draws upon complexity theory and the ecological sciences to emphasise bottom-up processes of emergence and adaptation (Batty 2012; Bai et al. 2016; Alberti 2017; Jepson Jr 2019; Ying et al. 2019; Lobo et al. 2020). There is a recognition that urban development is an outcome of non-linear and dynamic processes of continuous change rather than a convergence towards balance and equilibrium. As Batty (2012: S9) succinctly notes, 'cities are more like biological than mechanical systems.' This suggests that urban science should not be used to predict development patterns through the promotion of universal scientific laws but instead should focus on characterising the complex dynamics that produce the contemporary city. This requires fundamental shifts in the ontological and epistemological assumptions that underpin the New Urban Science and how urban science practitioners know as well as act upon cities.

\section{Towards an interdisciplinary urban science}

The emphasis on complexity, uncertainty, and emergence provides multiple opportunities for natural and social scientists to come together to analyse urban development processes. Here, the quantification of material flows and processes can be joined up with qualitative insights on politics and ideology, social structures and cultural differences, and modes of governance to recognise the contingent and emergent characteristics of 
urban development (Duminy and Parnell 2020). Data scientists, spatial modellers, and analysts can join together with urban planners and geographers, urban ecologists and environmental scientists, and political scientists and sociologists to compare and contrast different ways of knowing cities (Parnell and Robinson 2018; Lobo et al. 2020). In other words, the New Urban Science has the potential to embrace diversity and pluralism rather than a singular, all-encompassing perspective on urban knowledge production and application. There is a need for urban scientists of all stripes to find productive ways to uncover both the general and particular characteristics of urban development (Derudder and van Meeteren 2019). Likewise, urban science theories and methods need to go beyond a Global North perspective to include ideas from Southern Urbanism (Schindler 2017; Lawhon et al. 2020). These moves would challenge the dichotomies between the 'hard' and 'soft' sciences while forwarding a range of different geographic and scientific perspectives as complementary and productive rather than contradictory and divisive.

This merging of the natural and social sciences to inform the New Urban Science echoes longstanding calls for interdisciplinarity (Brand and Karvonen 2007; Barry et al. 2008; Petts et al. 2008; Barry and Born 2013; Nowotny et al. 2013). Interdisciplinarity involves the joining up of scholars from multiple fields to reorganise existing knowledge practices into new configurations (Acuto et al. 2018). It recognises that quantitative approaches are one way to study cities but these approaches involve particular ways of framing urban processes that are partial and incomplete (Kitchin 2016; Shelton 2017). Likewise, qualitative approaches provide situated and particular insights on cities but are often unable to provide generalisable insights on multi-scalar and complex modes of interaction between urban systems (Ramaswami et al. 2018). Together, quantitative and qualitative approaches can provide complementary and diverse perspectives on urban problems as well as proposed solutions while continuing to adhere to the tenets of validity, reliability, replicability, verification, and falsification that are essential to all scientific practices. In short, there is a need for a pluralist approach to the New Urban Science that capitalises on the strengths of all urban scientific knowledge practices (Petts et al. 2008; Derudder and van Meeteren 2019). As Lobo et al. (2020: 23) conclude, 'No one discipline should have prior claim on understanding cities.'

A concrete example of an interdisciplinary approach to the New Urban Science is the KTH Live-In Lab in Stockholm (KTH 2021). The Live-In Lab was launched in 2015 at the KTH Royal Institute of Technology as a real-world testbed for emerging building technologies. Researchers from the natural and social sciences use the facility to set up and perform laboratory experiments to generate data on the socio-technical dynamics of building performance related to energy and water consumption, building control systems, thermal comfort, cooking, and other issues (see Fig. 1). The lab is a physical space that facilitates disciplinary and interdisciplinary knowledge production on the complex dynamics of humans, technologies, and the built environment while producing new knowledge to inform urban policymaking and practice (Gieryn 2006; Karvonen and van Heur 2014).

The KTH Live-In Lab and similar facilities provide a venue where multiple scientific fields can collaborate. At the same time, their interdisciplinarity activities do not require the development of a singular, comprehensive ontology and epistemology to 


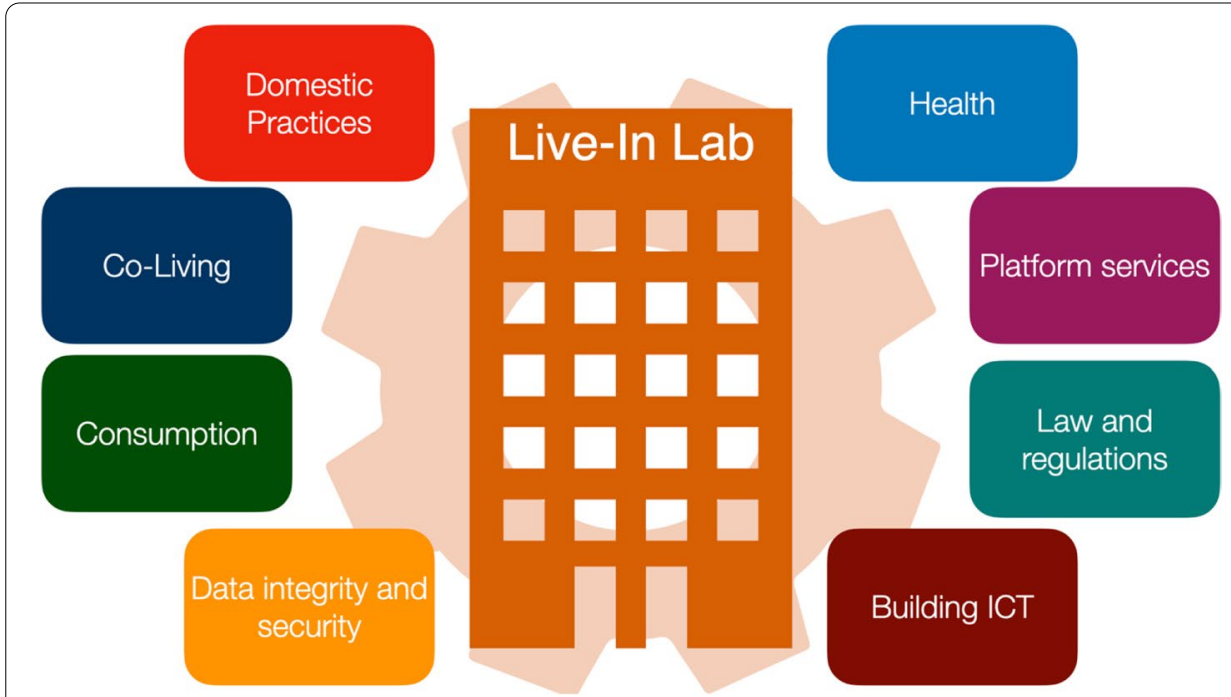

Fig. 1 Examples of research topics studied in the KTH Live-In Lab

be shared by all partners. Such a task would be impossible and also undermine the contributions of different perspectives and approaches to scientific knowledge production (Miller et al. 2008). Instead, interdisciplinarity forwards diversity and plurality as a strength but one that requires constant maintenance and attention and most importantly, a willingness to disagree. In other words, promoting pluralism among the sciences involves a healthy respect for, as well as scepticism of, different ontological and epistemological perspectives (Derudder and van Meeteren 2019). This requires humility and openness by all practitioners of urban science who 'recognise the value of other ways of knowing and doing' (Kitchin 2016: 5).

In our experiences of working as an interdisciplinary team, we have found that seemingly simple tasks of defining key terms and articulating how urban change occurs are often difficult and laborious but necessary to productive collaboration. A significant part of engaging in interdisciplinary science involves working at the boundaries and identifying synergies and tensions between disciplines (Robinson 2008). It calls for a community of scientists that is open to debate and disagreement about theories and methods (Duminy and Parnell 2020). The reward for this labour is the potential to develop new insights from the frictions between multiple knowledges.

The commitment to interdisciplinarity is evident in the current research on smart cities that has supplemented the focus on technological efficacy with social, political, and cultural perspectives to acknowledge the unavoidable politics of sociotechnical change (Coletta et al. 2019; Karvonen et al. 2019, 2020; Willis and Aurigi 2020; Miller et al. 2021). Likewise, there are parallel developments in urban ecology and the emphasis on complex adaptive systems to characterise the dynamics between nature, technology, the built environment, and urban residents (McPhearson et al. 2016, Alberti 2017). An interdisciplinary New Urban Science would recognise the value in other ways of knowing and doing that can make scientific practices in cities more relevant and robust (Kitchin 2016; Parnell and Robinson 2018). 


\section{From interdisciplinary to transdisciplinary urban science}

Despite the challenges of navigating the multiple diverse knowledges of various natural and social sciences, interdisciplinary collaboration is necessary but insufficient to expand and enhance the New Urban Science. Knowledge generation practices arguably need to extend beyond the scientific community to include stakeholders from the public and private sectors as well as civil society. Such a 'quadruple helix' approach recognises the need to reimagine existing science-policy and science-society interfaces to ensure that research activities are relevant to and aligned with the needs of society at large (Acuto et al. 2018; Washbourne et al. 2021). The terms 'interdisciplinary' and transdisciplinary' are often used interchangeably but here, we treat them as distinct concepts with different implications for urban knowledge production and application. Interdisciplinary refers to scientific practices that emerge from multiple disciplines and result in novel approaches within the academy while transdisciplinary refers to scientific practices that go beyond the academy to co-produce knowledge with urban stakeholders (Brandt et al. 2013; Toomey et al. 2015; Ramaswami et al. 2018; Buyana et al. 2021). Transdisciplinarity is a collaborative approach to knowledge development that forwards a holistic perspective to leverage multiple opportunities for transformational change (Webb et al. 2018) .

One way that transdisciplinary urban science is currently being practiced is through global networks involving diverse group of stakeholders that focus on shared issues (Davidson et al. 2019; Acuto et al. 2019; Acuto and Leffel 2020; Nguyen et al. 2020). Bai et al. (2019) note that today, there are over 200 urban-oriented global networks where urban stakeholders from academia, public policy, private practice, and civil society exchange information and experiences. Networks such as the Rockefeller 100 Resilient Cities programme, the C40 Cities Climate Leadership Group, the Global Covenant of Mayors for Climate and Energy, ICLEI Local Governments for Sustainability, and the Urban Knowledge Action Network provide multiple opportunities to expand the New Urban Science by including a wide range of stakeholders who circulate findings and insights through peer-to-peer interaction and collaborative learning. The emerging community of practice around urban science is essential to governing innovation and change by connecting up local experiences with global impacts (Bai et al. 2019).

Global urban networks are an important and highly visible approach to transdisciplinary science but urban knowledge production also involves situated, place-specific activities involving local stakeholders. Citizen science, participatory action research, and crowdsourcing of data exemplify participatory approaches to transdisciplinary science where research is a distributed and applied activity (Mattern 2013; Townsend 2015c; Townsend and Chisholm 2015). This is particularly evident in urban experiments, laboratories, testbeds, and innovation districts where scientific research involves both scientific and non-scientific stakeholders through activities of situated knowledge production and application (Evans et al. 2016; Marvin et al. 2018). A transdisciplinary approach steers scientific practices towards those issues that are relevant to urban residents while opening up knowledge production processes to other perspectives. In the best of cases, it creates local communities of practice and learning networks (Wolfram et al. 2019) while democratising the production of scientific knowledge (Bäckstrand 2003). 
In all of these endeavours, there is a strong emphasis on developing new modes of learning that can influence urban development (McFarlane 2011; Bai et al. 2019). It recognises that knowledge derived from the New Urban Science is not valuable in and of itself but needs to be taken up and applied. And it is through the application of scientific findings that the New Urban Science demonstrates its real worth to society, specifically to improve the lives of urban residents. Examples of an engaged and inclusive approach to the New Urban Science include Amsterdam's Smart Citizens Lab, the Barcelona Digital City programme, and the Gauteng CityRegion Observatory in South Africa (Waag 2021; Barcelona City Council 2021; Washbourne et al. 2021). These initiatives make explicit connections between scientific knowledge generation and the uptake and application of scientific findings by local governments (Townsend 2015b; Acuto et al. 2018). They provide a direct route for urban science findings to influence policy making (Lobo et al. 2020; Raimbault et al. 2020).

Another programme that exemplifies transdisciplinary urban science is Digital Demo Stockholm, a 'quadruple-helix' innovation partnership that includes academia, government, business, and civil society (Digital Demo Stockholm 2021). The programme was launched in 2016 and provides a platform for scientists and nonscientists to collaborate on applied research projects with urban residents to realise Stockholm's ambitions to be the world's smartest city by 2040. The stakeholders engage in the design, development, and monitoring of real-world digitalisation experiments related to communication and logistics systems, water and energy monitoring and management, and health and elderly care (see Table 1). The city is framed as a testbed for innovation trials to inform future digitalisation policies and programmes while creating new connections between stakeholders.

Despite the promise of these projects to realise new transdisciplinary modes of urban science, there continue to be multiple challenges in realising productive collaboration between scientists, practitioners, and civil society (Petts et al. 2008; Palmer et al. 2020). Urban stakeholders have a wide range of ideas about the purpose of scientific research and how it should be conducted most effectively (Haarstad et al. 2018). Transdisciplinary urban science presents significant challenges to all urban stakeholders due to different worldviews and ways of working. Thus, there is a need to focus on how transdisciplinary knowledge production is conducted and to manage expectations among the various actors about what urban science can and cannot achieve.

Table 1 Examples of Digital Demo Stockholm Projects

\begin{tabular}{|c|c|}
\hline Project & Description \\
\hline iWater & Development of a real-time sensor network to measure water quality \\
\hline TechTensta & Design of a high-tech youth centre to promote learning and inspire creativity \\
\hline Smart Locks & Trialling keyless solutions to facilitate care worker visits to elderly residents in their homes \\
\hline Energy-Efficient Care & Design and testing of a control system to optimise energy management in hospitals \\
\hline User-Centred Care & $\begin{array}{l}\text { Development of a digital support and communication systems to enhance home-based } \\
\text { care for elderly residents }\end{array}$ \\
\hline
\end{tabular}




\section{Developing and enacting urban transformative capacity}

The New Urban Science offers great potential to harness the power and energy of the digitalisation of cities to develop new ways of knowing and acting upon urban development processes while directing applied research activities towards beneficial societal outcomes. However, we argue that to realise its full potential, the New Urban Science needs to embrace expansive modes of knowledge production that are simultaneously interdisciplinary and transdisciplinary. As Acuto et al. (2018: 2) summarise:

In order for urban science to be collectively greater than the sum of its parts, it needs to draw from all the sciences - natural, engineering, and social, as well as the arts, and humanities - whilst linking directly into practice, and offering effective global assessments of the state of our planet's urban condition.

This suggests the need for plural 'New Urban Science' rather than a singular 'New Urban Science' that draws upon a wide range of scientific disciplines and stakeholders to characterise and interpret urban conditions. Urban data analytics are only one way that the New Urban Science should be practiced (Duminy and Parnell 2020). There is no single way to know cities but multiple ways that provide partial insights. Moreover, scientific practices need to be understood as collaborative rather than competitive (Petts et al. 2008). This embodies the first challenge of an expanded New Urban Science: to recognise urban knowledge production as a pluralist endeavour.

A second challenge relates to the development of scientific practices that go beyond the academy to include a wide range of urban stakeholders. The emphasis on transdisciplinary collaboration blurs the boundaries between formally trained scientists who study cities and the practitioners, policymakers, and residents who regulate, design, construct, and live in these places. From this perspective, the New Urban Science provides new opportunities for academic and non-academic actors to develop new approaches to collaboration (Duminy and Parnell 2020). It also requires urban scientists to acknowledge that scientific knowledge production is only one way of knowing cities. Academic colleagues in the humanities and other non-scientific disciplines, as well as policymakers, designers, and residents can make valuable contributions to the New Urban Science.

A third challenge to the New Urban Science is to identify ways to apply the insights from interdisciplinary and transdisciplinary collaboration to improve urban conditions. The communities of learning and doing engage in the New Urban Science can be used to support urban transformative capacity (Wolfram 2016; Wolfram et al. 2019; Hölscher and Frantzeskaki 2021) and steer urban development in radically new directions (Castan Broto et al. 2019). Urban transformative capacity is fuelled by local knowledge as well as global knowledge through processes of institutional and social learning to diagnose existing problems, recognise connections, and devise interventions. Knowledge transfer, upscaling, rolling out, and seeding are some of the ways that urban science findings can be translated and applied to governance processes (Kern 2019; Lam et al. 2020). This requires scientific stakeholders to plan in advance how their work can directly inform urban development processes.

In conclusion, the New Urban Science holds significant promise to provide new ways of knowing and acting upon cities through interdisciplinary and transdisciplinary collaboration to produce actionable knowledge. However, this will require fundamental 
changes to the ways that we develop and apply urban scientific knowledge (Acuto et al. 2018). This raises important questions about which urban scientists generate knowledge about cities and how this knowledge is mobilised to affect change (Washbourne et al. 2021). An expanded New Urban Science requires new theories and methods to understand and affect change in cities while also acknowledging blind spots as well as other non-scientific forms of urban knowledge production (Parnell and Robinson 2018; Lobo et al. 2020). It is our responsibility as engaged scientists to formulate robust and compelling theories and methods that are effective and socially relevant to produce cities of the twenty-first century that are sustainable, resilient, and liveable.

\section{Code availability}

Not applicable.

\section{Funding}

This article is supported by the Digital Futures research project 'Humanizing the Sustainable Smart City'. For more information on Digital Futures, see www.digitalfutures.se. Open access funding provided by Royal Institute of Technology.

Availability of data and materials

Not applicable.

\section{Declarations}

Ethics approval and consent to participate

Not applicable.

\section{Consent for publication}

Not applicable.

\section{Competing interests}

Not applicable.

Received: 21 December 2020 Accepted: 19 October 2021

Published: 2 November 2021

\section{References}

Acuto M, Leffel B. Understanding the global ecosystem of city networks. Urb Stud. 2020;58(9):1758-74.

Acuto M, Parnell S, Seto KC. Building a global urban science. Nat Sust. 2018;1:2-4.

Acuto M, Steenmans K, Iwaszuk E, Ortega-Garza L. Informing urban governance? Boundary-spanning organisations and the ecosystem of urban data. Area. 2019:51(1):94-103.

Alberti M. Grand challenges in urban science. Front Built Env. 2017;3(6):31-5.

Bäckstrand K. Civic science for sustainability: reframing the role of experts, policy-makers and citizens in environmental governance. Glob Env Pol. 2003;3(4):24-40.

Bai X, Colbert M, McPhearson T, Roberts D, Siri J, Walsh B, et al. Networking urban science, policy and practice for sustainability. Curr Opin Environ Sus. 2019;39:114-22.

Bai X, Surveyer A, Elmqvist T, Gatzweiler FW, Güneralp B, Parnell S, et al. Defining and advancing a systems approach for sustainable cities. Cur Opin Env Sust. 2016;1 (23):69-78.

Barcelona City Council. Barcelona Digital City, 2021. Available at https://ajuntament.barcelona.cat/digital.

Barry A, Born G. Interdisciplinarity: reconfigurations of the social and natural sciences. London: Routledge; 2013.

Barry A, Born G, Weszkalnys G. Logics of interdisciplinarity. Econ Soc. 2008;37(1):20-49.

Batty M. Building a science of cities. Cities. 2012;29:S9-S16.

Batty M. The new science of cities. London: MIT Press; 2013

Berry BJ. Cities as systems within systems of cities. Papers Reg Sci. 1964;13(1):147-63.

Bettencourt LMA. Introduction to urban science: evidence and theory of cities as complex systems. London: MIT Press; 2021.

Brand R, Karvonen A. The ecosystem of expertise: complementary knowledges for sustainable development. Sust: Sci Prac Pol. 2007;3(1):21-31.

Brandt P, Ernst A, Gralla F, Luederitz C, Lang DJ, Newig J, et al. A review of transdisciplinary research in sustainability science. Ecol Econ. 2013;92:1-15.

Buyana K, Walubwa J, Mukwaya P, Lwasa S, Owuor S. City residents, scientists and policy-makers: power in co-producing knowledge. Urban Transform. 2021;3(1):1-12.

Calzada I. Smart city citizenship. London: Elsevier; 2020.

Carr C, Hesse M. When alphabet Inc. plans Toronto's waterfront: new post-political modes of urban governance. Urban Plan. 2020:5(1):69-83. 
Castan Broto V, Trencher G, Iwaszuk E, Westman L. Transformative capacity and local action for urban sustainability. Ambio. 2019;48(5):449-62.

Coletta C, Evans L, Heaphy L, Kitchin R, editors. Creating smart cities. London: Routledge; 2019.

Davidson $\mathrm{K}$, Coenen L, Acuto M, Gleeson B. Reconfiguring urban governance in an age of rising city networks: a research agenda. Urb Stud. 2019;56(16):3540-55.

Derudder B, van Meeteren M. Engaging with 'urban science'. Urb Geog. 2019;40(4):555-64.

Dewey D. The public and its problems. Athens: Swallow Press; 1927. [1954]

Digital Demo Stockholm. 2021. Website, available at https://www.digitaldemostockholm.com, Accessed 18 Oct 2021.

Duarte F, Ratti C. The impact on autonomous vehicles on cities: a review. Jrnl Urb Tech. 2018;25(6):1-16.

Duminy J, Parnell S. City science: a chaotic concept-and an enduring imperative. Plan Theory Pract. 2020;21(4):648-55.

Evans J, Karvonen A, Raven R, editors. The experimental city. London: Routledge; 2016.

Fainstein SS. The just city. Intl Jrnl Urb Sci. 2014;18(1):1-18.

Gieryn TF. City as truth-spot: laboratories and field-sites in urban studies. Soc Stud Sci. 2006;36(1):5-38.

Graham S, Marvin S. Splintering urbanism: networked infrastructures, technological mobilities and the urban condition. London: Routledge; 2001.

Haarstad H, Sareen S, Wanvik TI, Grandin J, Kjærås K, Oseland SE, et al. Transformative social science? Modes of engagement in climate and energy solutions. Energy Rsrch Soc Sci. 2018;42:193-7.

Healey P, Hillier J. The ashgate research companion to planning theory: conceptual challenges for spatial planning. Farnham: Ashgate; 2010.

Hölscher K, Frantzeskaki N. Perspectives on urban transformation research: transformations in, of, and by cities. Urban Transform. 2021;3(2):1-14.

Jepson EJ Jr. Sustainability science and planning: a crucial collaboration. Plan Theory Prac. 2019;20(1):53-69.

Karvonen A. Urban techno-politics: knowing, governing, and imagining the city. Sci Cult. 2020;29(3):417-24.

Karvonen A, Cook M, Haarstad H. Urban planning and the smart city: projects, practices and politics. Urban Plan. 2020;5(1):65-8.

Karvonen A, Cugurullo F, Caprotti F, editors. Inside smart cities: place, politics and urban innovation. London: Routledge; 2019.

Karvonen A, van Heur B. Urban laboratories: experiments in reworking cities. Intl Jrnl Urb Reg Rsrch. 2014;38(2):379-92.

Kern K. Cities as leaders in EU multilevel climate governance: embedded upscaling of local experiments in Europe. Environ Pol. 2019;28(1):125-45.

Kitchin R. The ethics of smart cities and urban science. Phil Trans Royal Soc A: Math, Phys Eng Sci. 2016;374(2083):20160115.

Kitchin R. Urban science: prospect and critique. In: Willis K, Auguri A, editors. The routledge companion to smart cities. London: Routledge; 2020. p. 42-50.

Kitchin R, Lauriault TP, McArdle G. Knowing and governing cities through urban indicators, city benchmarking and realtime dashboards. Reg Stud Reg Sci. 2015;2(1):6-28.

KTH. KTH live-in lab, 2021. Available at https://www.liveinlab.kth.se.

Lam DPM, Martín-López B, Wiek A, Bennett EM, Frantzeskaki N, Horcea-Milcu Al, et al. Scaling the impact of sustainability initiatives: a typology of amplification processes. Urb Trans. 2020;2:1-24.

Lawhon M, Le Roux L, Makina A, Nsangi G, Singh A, Sseviiri H. Beyond southern urbanism? Imagining an urban geography of a world of cities. Urb Geog. 2020;41(5):657-67.

LeGates R, Tate NJ, Kingston R. Spatial thinking and scientific urban planning. Env Plan B: Plan Des. 2009;36(5):763-8.

Light JS. From warfare to welfare: defense intellectuals and urban problems in cold war america. London: Johns Hopkins Uni Press; 2003.

Lobo J, Alberti M, Allen-Dumas M, Arcaute E, Barthelemy M, Bojorquez Tapia LA, et al. Urban science: integrated theory from the first cities to sustainable metropolises. Report submitted to the NSF on the present state and future of urban science; 2020. p. 38. available at https://ssrn.com/abstract $=3526940$

Marvin S, Bulkeley H, Mai L, McCormick K, Palgan YV, editors. Urban living labs: experimenting with city futures. London: Routledge; 2018.

Marvin S, Luque-Ayala A. Urban operating systems: diagramming the city. Int Jrnl Urb Reg Rsrch. 2017;41 (1):84-103.

Mattern S. Methodolatry and the art of measure. Places J. 2013; May: https://doi.org/10.22269/131105.

McFarlane C. Learning the city: knowledge and translocal assemblage. London: Wiley; 2011.

McPhearson T, Parnell S, Simon D, Gaffney O, Elmqvist T, Bai X. et al. Scientists must have a say in the future of cities. Nature. 2016;538:165-6.

Melosi MV. The sanitary city: environmental services in urban America from colonial times to the present. Pittsburgh: Uni Pitt Press; 2008.

Miller B, Ward K, Burns R, Fast V, Levenda A. Worlding and provincialising smart cities: from individual case studies to a global comparative research agenda. Urb Stud. 2021;58(3):655-73.

Miller TR, Baird TD, Littlefield CM, Kofinas G, Chapin FS, Redman CL. Epistemological pluralism: reorganizing interdisciplinary research. Ecol Soc. 2008;13(2):46.

Morgan K, Webb B. Googling the city: in search of the public interest on Toronto's 'smart'waterfront. Urban Plan. 2020;5(1):84-95.

Nguyen TMP, Davidson K, Coenen L. Understanding how city networks are leveraging climate action: experimentation through C40. Urban Transform. 2020;2(12):1-23.

Nowotny H, Scott PB, Gibbons MT. Re-thinking science: knowledge and the public in an age of uncertainty. London: Wiley; 2013.

Palmer H, Polk M, Simon D, Hansson S. Evaluative and enabling infrastructures: supporting the ability of urban coproduction processes to contribute to societal change. Urban Transform. 2020;2(6):1-14.

Park RE, Burgess EW. The city. Chicago: Uni Chi Press; 2019.

Parnell S, Robinson J. The global urban: difference and complexity in urban studies and the science of cities. In: Hall S, Burdett R, editors. The sage handbook of the $21^{\text {st }}$ century city. London: SAGE Publications; 2018. p. 13-31. 
Petts J, Owens S, Bulkeley H. Crossing boundaries: interdisciplinarity in the context of urban environments. Geoforum. 2008;39(2):593-601.

Raimbault J, Denis E, Pumain D. Empowering urban governance through urban science: multi-scale dynamics of urban systems worldwide. Sust. 2020;12:5954.

Ramaswami A, Bettencourt L, Clarens A, Das S, Fitzgerald G, Irwin E, et al. Sustainable urban systems: articulating a longterm convergence research agenda. A report by the advisory committee for environmental research and education. Washington, D.C.: National Science Foundation; 2018.

Rittel HW, Webber MM. Dilemmas in a general theory of planning. Pol Sci. 1973;4(2):155-69.

Robinson J. Being undisciplined: transgressions and intersections in academia and beyond. Futures. 2008;40(1):70-86.

Schindler S. Towards a paradigm of southern urbanism. City. 2017;21(1):47-64.

Schultz SK, McShane C. To engineer the metropolis: sewers, sanitation, and city planning in late-nineteenth-century America. Jrnl Amer Hist. 1978;65(2):389-411.

Shelton T. The urban geographical imagination in the age of big data. Big Data Soc. 2017:4(1):205395171666512.

Shutters ST. Urban science: putting the "smart" in smart cities. Urb Sci. 2018;2(94):1-4.

Söderström O, Paasche T, Klauser F. Smart cities as corporate storytelling. City. 2014;18(3):307-20.

Solecki W, Seto KC, Marcotullio PJ. It's time for an urbanization science. Env: Sci Pol Sust Dev. 2013;55(1):12-7.

Toomey AH, Markusson N, Adams E, Brockett B. Inter-and trans-disciplinary research: a critical perspective. GSDR 2015 brief; 2015

Townsend A. The future of urban science: new horizons in research on human settlements. New York: Rudin Center for Trans Pol \& Mgmt, NYU; 2015a.

Townsend A. Making sense of the new urban science. New York: Rudin Center for Trans Pol \& Mgmt, NYU; $2015 b$.

Townsend A. Cities of data: examining the new urban science. Pub Cult. 2015c;27(2):201-12.

Townsend A, Chisholm A. Citizen urban science: new partnerships for advancing knowledge. New York: Rudin Center for Trans Pol \& Mgmt, NYU; 2015.

Waag. 2021. Waag Smart Citizens Lab, Available from https://waag.org/en/lab/smart-citizens-lab.

Washbourne C-L, Culwick C, Acuto M, Blackstock JJ, Moore R. Mobilising knowledge for urban governance: the case of the Gauteng City-region observatory. Urban Res Pract. 2021;14(1):27-49.

Webb R, Bai X, Smith MS, Costanza R, Griggs D, Moglia M, et al. Sustainable urban systems: co-design and framing for transformation. Ambio. 2018;47(1):57-77.

Willis KS, Aurigi A, editors. The routledge companion to smart cities. London: Routledge; 2020.

Wolfram M. Conceptualizing urban transformative capacity: a framework for research and policy. Cities. 2016;51:121-30.

Wolfram M, Borgström S, Farrelly M. Urban transformative capacity: from concept to practice. Ambio. 2019;48(5):437-48.

Ying L, Tian T, Xiaojie S. (new) urban science: studying 'new' cities with new data, methods, and technologies. Land Arch Front. 2019;7(2):8-22.

Zellner M, Campbell SD. Planning for deep-rooted problems: what can we learn from aligning complex systems and wicked problems? Plan Theory Pract. 2015;16(4):457-78.

\section{Publisher's Note}

Springer Nature remains neutral with regard to jurisdictional claims in published maps and institutional affiliations.

- fast, convenient online submission

- thorough peer review by experienced researchers in your field

- rapid publication on acceptance

- support for research data, including large and complex data types

- gold Open Access which fosters wider collaboration and increased citations

- maximum visibility for your research: over 100M website views per year

At BMC, research is always in progress.

Learn more biomedcentral.com/submissions 